\title{
AKSARA TAFSIR AL-QUR'AN DI PRIANGAN:HURUF PEGON DAN AKSARA LATIN DALAM KARYA K.H. AHMAD SANOESI
}

\author{
Yani Yuliani ${ }^{*}$ \\ 1 Fakultas Ushuludin UIN Sunan Gunung Jati Bandung, Jl. AH. Nasution No. 105 Bandung, Jawa Barat, \\ Indonesia; Email: yaniyuliani342@gmail.com \\ * Correspondence
}

Received: 2020-05-07; Accepted: 2020-06-30 Published: 2020-07-21

\begin{abstract}
This study focuses on the use of both pegon and Latin or Roman scripts in the writing of the Quranic exegesis in Priangan, West Java. The object of research is the works of Ahmad Sanoesi (1880-1950), namely Sundanese tafsìr of Raudat al-Irfän and Malja' al-Tālibīn which use pegon scripts and Malay or Indonesian tafsìr of Tamsjijjatoel Moeslimien which uses Latin scripts. This research employs social history and a hermeneutic approach. This study confirms that the use of pegon and Latin scripts related to the different backgrounds of Muslim reader segmentation. It was not only written for the santri of pesantren who were generally only able to read pegon writings, but also for the wider community who were able to read Latin scripts. Raudat al-Irfān and Malja' al-Tälibìn which used Sundanese pegon scripts were written for the santri of Sundanese pesantren in Priangan. Meanwhile, Tamsjijjatoel Moeslimien, which used Indonesian Latin scripts was written for the wider Indonesian community. The use of these two types of scripts also then affects the differences in Sanoesi's interpretation of the Quran. Explanations of Qur'anic verses dominated Raudat al-Irfän and Malja' al-Tälibin through the knowledge of Qur'an and tafsir which are generally only understood by santri in Priangan. In contrast, Tamsjijjatoel Moeslimien was generally dominated by explanations which understood by a broad audience.
\end{abstract}

Keywords: Quranic exegesis; scripts; reader, segmentation; substance.

Abstrak: Kajian ini memfokuskan pada penggunaan huruf pegon dan aksara latin dalam penulisan tafsir Al-Qur'an di Priangan, Jawa Barat. Objek kajiannya adalah tafsir karya K.H. Ahmad Sanoesi (1880-1950), yaitu Raudat al-'Irfān dan Malja' al-Tālibīn yang beraksara pegon dengan bahasa Sunda serta Tamsjijjatoel Moeslimien yang beraksara latin dalam bahasa Indonesia. Melalui pendekatan sejarah sosial dan hermeneutik, kajian ini menegaskan bahwa penggunaan kedua aksara tersebut terkait dengan latar perbedaan segmentasi pembaca. Tidak hanya ditulis untuk kalangan pesantren yang umumnya saat itu hanya mampu membaca teks huruf pegon, tetapi juga untuk masyarakat luas yang mampu membaca teks aksara latin. Rauḍat al-'Irfān dan Malja' al-Ṭälibìn ditulis untuk kepentingan santri dan kiai pesantren di Priangan, sedangkan Tamsjijjatoel Moeslimien ditulis untuk masyarakat Indonesia secara lebih luas. Penggunaan dua jenis aksara tersebut juga kemudian berdampak pada perbedaan substansi penafsiran Sanoesi terhadap ayat Al-Qur'an. Raudat al-'Irfān dan Malja' al-Tâlibìn yang beraksara pegon lebih didominasi oleh penjelasan ayat melalui perangkat keilmuan Al-Qur'an dan tafsir yang umumnya hanya dapat dipahami oleh kaum santri di Priangan, sedangkan Tamsjijjatoel Moeslimien yang beraksara latin didominasi penjelasan yang bercirikan kepentingan masyarakat umum sehingga dapat dipahami oleh khalayak luas.

Kata Kunci: Tafsir; aksara; pembaca; segmentasi; substansi. 


\section{Pendahuluan}

Tafsir Alquran di Indonesia disajikan dengan bahasa dan aksara yang sangat beragam. Bukan hanya bahasa Arab, tetapi juga bahasa lokal-daerah seperti Melayu, Aceh, Jawa, Sunda, Bugis, Madura dan lainnya. Bukan hanya ditulis menggunakan huruf Arab, tetapi juga aksara Jawa (carakan), lontara, latin, huruf jawi, pegon dan lainnya. Bahasa dan aksara yang beragam tersebut tentu saja dimaksudkan untuk memudahkan pembaca dalam memahami kandungan Alquran(Hussin, et al., 2016) (Bilmauidhah, 2011, hal. 41-62; Kiptiah, n.d., hal. 420-445; Mursalim, 2009).

Salah satu aksara yang digunakan dalam penulisan tafsir adalah huruf pegon. Huruf ini merupakan huruf Arab yang digunakan untuk menuliskan bahasa Jawa, Madura dan Sunda. Sebagaimana huruf Arab-Melayu atau jawi di daerah Sumatra, huruf pegon termasuk ke dalam jenis tulisan asing yang sampai ke Nusantara seperti halnya aksara Jawa, Sunda dan lainnya yang berasal dari India dan aksara latin dari Eropa. Pegon menunjukkan sebuah pengalihan dari huruf Arab ke dalam huruf yang hampir sama untuk menuliskan bahasa Jawa, Madura dan Sunda. Sebuah pengalihan yang menyerap huruf asalnya ke dalam tulisan lain. Setiap kali tulisan baru diserap, ia menunjukkan suatu pengaruh budaya yang sangat besar. Huruf Arab yang diserap menjadi pegon menunjukkan pengaruh besar budaya Arab terhadap budaya Nusantara. Ia kemudian selalu menghasilkan penyerapan sejumlah kata asing berbahasa Arab dan penerjemahan sejumlah teks Arab ke dalam tulisan pegon(Roger Tol, et al., 2009, hal. 309).

Di tatar Sunda, penggunaan huruf pegon untuk penulisan tafsir Alquran dilakukan oleh salah seorang ulama terkenal, K.H. Ahmad Sanoesi (1880-1950). Ia misalnya, menulis tafsir Malja' al-Tālibīn (tempat berlindung para siswa) tahun 1930-an saat dibuang di Batavia Centrum, lalu menulis Raudat al-'Irfān (kebun pengetahuan) saat kembali dari pengasingan. Keduanya dan banyak sekali karya tafsir lainnya ditulis menggunakan huruf pegon. Ia menggunakan huruf tersebut dalam kebanyakan karyanya di bidang keilmuan Islam. Hal ini dilakoni sepanjang hidupnya, paling tidak sejak ia menulis Nahrah Dargham (suara singa wilayah) saat di Mekah (1914), lalu berlanjut saat di Pesantren Cantayan (1915-1921), Pesantren Babakan Sirna Genteng (1921-1927), dibuang ke Batavia Centrum (1928-1934), tahanan kota di Sukabumi (1934-1939), hingga beberapa tahun jelang wafatnya (19391942)(Saleh, 2016).

Namun, perhatian Sanoesi rupanya tidak hanya pada huruf pegon, ia juga belakangan menggunakan aksara latin dalam menulis karyanya, salah satunya tafsir berbahasa Indonesia, Tamsjijjatoel Moeslimien (perjalanan kaum Muslimin) tahun 1934. Tafsir ini diterbitkan saat Sanoesi selesai menjalani masa tahanan dari Batavia Centrum lalu pindah ke Sukabumi sebagai tahanan kota tahun 1934-1939. Bahkan tafsir ini kemudian memicu polemik di kalangan ulama Priangan, karena dianggap tidak layak digunakan untuk menuliskan Alquran. Selain huruf Arab, Sanoesi juga menampilkan transliterasi tulisan Alquran dalam aksara latin(Darmawan, 2009, hal. 110). Meski terjadi penolakan, Tamsjijjatoel Moeslimien terus diterbitkan bahkan hingga mencapai Singapura. Pertanyaannya, Mengapa Sanoesi memilih menulis tafsir tidak hanya dengan huruf pegon, tetapi juga aksara latin yang akhirnya memicu kontroversi? Apa faktor penyebab utama yang mendorong Sanoesi menulis tafsirnya dengan kedua aksara tersebut? Apakah penggunaan aksara yang berbeda berpengaruh pula terhadap substansi penafsiran Sanoesi terhadap ayat Alquran?

Artikel ini memfokuskan pada penggunaan huruf pegon dan aksara latin dalam penulisan tafsir Alquran karya Sanoesi. Mengingat begitu banyaknya karya tafsir Sanoesi, maka tidak semua karya tafsirnya dijadikan objek kajian(Basri, 2003; Matin, 2009, hal. 147-164). Hanya tiga karya tafsirnya yang digunakan untuk kepentingan kajian ini, yaitu Raudat al-'Irfān dan Malja' al-Tälibìn yang berhuruf pegon dan Tamsjijjatoel Moeslimien yang beraksara latin. Kajian ini menggunakan pendekatan sejarah sosial untuk menganalisis ragam faktor sosial intelektual yang mempengaruhi terjadinya peristiwa sejarah, yaitu dinamika penulisan karya tafsir Sanoesi dalam rentang waktu 1930-1934(MacRaild et al., 2004, hal. 18). Pilihan ketiga tafsir karya Sanoesi tersebut didasarkan pada 
dekatnya rentang waktu penerbitannya dibanding karya tafsir lainnya. Selain itu, digunakan pula pendekatan hermeneutik untuk memahami posisi dunia pembaca dalam lingkaran triadik teks tafsir yang tidak dapat dilepaskan dari dunia pengarang dan dunia teks itu sendiri(Seebohm, 2004, hal. 40).

Sepengetahuan penulis, meski sudah sangat banyak sarjana yang menulis tentang Sanoesi dan karya-karyanya(Basri, 2003, hal. 225-241; Iskandar, 2001; Manshur, 1992, hal. 9-16), termasuk karya tafsirnya(A.Rohmana, 2015, hal. 297-2332, 2017, hal. 25-58; Darmawan, 2009; Manshur, 1992; Umar, n.d., hal. '153-180), tetapi yang memfokuskan pada posisi aksara yang digunakan Sanoesi dalam karyanya tidak banyak mendapat perhatian. Kiranya hanya tulisan Gusmian yang pernah membahas tentang penggunaan aksara dan bahasa dalam penulisan tafsir Alquran, meskipun dalam konteks Indonesia dan tafsir bahasa Jawa(Gusmian, n.d., hal. 141-168, 2010, 2015, hal. 233-247), Karenanya, kajian ini berusaha mengisi ruang kosong kajian para sarjana tersebut, sehingga dapat berkontribusi dalam studi aksara penulisan tafsir di Indonesia.

Selain itu, pengungkapan alasan di balik penggunaan huruf pegon dan aksara latin dalam penulisan tafsir Alquran penting dilakukan untuk menjernihkan posisi penggunaan huruf tersebut dalam konteks kolonialisme Belanda. Beberapa sarjana mengklaim bahwa penggunaan huruf pegon oleh kalangan pesantren sebagai bentuk perlawanan simbolis terhadap kolonial yang mewacanakan aksara latin(Fikri, 2014, hal. 82; Gusmian, n.d., hal. 157-158; Mustaqim, 2017, hal. 360,372), Tetapi, sebagaimana akan dijelaskan, penggunaan huruf pegon dan aksara latin sama sekali tidak ada hubungannya dengan bentuk perlawanan itu. Buktinya, meski Sanoesi dikenal sangat anti kolonial, tetapi Sanoesi menggunakan kedua jenis aksara tersebut dalam tulisan tafsirnya. Kajian ini kiranya sangat penting untuk mendudukkan masalah tersebut yang dalam kasus Sanoesi sama sekali tidak relevan untuk dijadikan dasar dalam perlawanan anti kolonial.

\section{Huruf Pegon dan Aksara Latin}

Karakteristik huruf pegon dan aksara latin yang digunakan dalam penulisan tafsir Alquran di Jawa Barat. Penjelasan ini penting untuk menunjukkan perbedaan di antara kedua aksara tersebut. Di Jawa Barat, huruf pegon merupakan tulisan Arab untuk bahasa Sunda, maka diperlukan kemampuan bahasa Sunda sebagai perangkat dasar agar dapat membacanya. Hanya orang yang memiliki kemampuan membaca huruf Arab dan menguasai bahasa Sunda saja yang dapat membaca teks berhuruf pegon tersebut. Meskipun huruf pegon berasal dari huruf Arab, tetapi karena bahasa dasarnya adalah bahasa Sunda, maka cara baca dan penulisannya pun memiliki sedikit perbedaan dengan huruf Arab biasa.

Terdapat beberapa ciri yang membedakan huruf pegon dengan aksara lainnya, di antaranya: 1) huruf ini ditulis dari kanan ke kiri, sebagaimana terdapat dalam teks beraksara Arab pada umumnya; 2) keseluruhan jumlah huruf pegon ada 33 huruf, berbeda dengan huruf Arab biasa yang berjumlah 30 huruf, tetapi huruf-huruf itu tidak semuanya digunakan dalam bahasa Sunda. Karenanya, hurufhuruf seperti $t z, k h, d z, z, s y, d l, t l, t h$, '('ain), g (ghain), $f$ dan $q$ hanya digunakan untuk kata asing yang bersumber dari bahasa Arab; 3) bunyi huruf vokal pada huruf pegon sama dengan huruf Arab umumnya, yaitu mengikuti pola $i^{\prime} r a b$, yaitu bunyi $a$ disebut jabar dinyatakan dengan 4] $\left.\backslash 714\right]$ berupa garis miring pendek di atas huruf bersangkutan; bunyi $i$ disebut jeer dan diberi tanda dengan kasrah berupa garis miring pendek di bawah hurufnya; bunyi $u$ disebut pees dan diberi tanda dengan dhammah, yaitu $\mathrm{G}$ kecil di atas huruf bersangkutan; bunyi é bernama panéléng diberi tanda dengan fathah di atas huruf serta di belakang huruf itu, misalnya éh (ايه); bunyi o bernama panolong dinyatakan dengan fathah di atas hurufnya disertai 9 di belakang hurufnya, misalnya bol (بول); untuk e pepet digunakan huruf hamzah tetapi bentuknya agak diubah, meskipun tidak jelek karena dalam tulisan Arab pun hamzah dipakai ketika tidak ada vokal; sedangkan untuk eu paneuleung digunakan tanda di atas huruf bersangkutan(Coolsma, 1985, hal. 9-10).

Huruf pegon sepenuhnya mengadopsi huruf Arab (hijaiyyah) yang berjumlah 30 huruf, hanya saja dalam huruf pegon terdapat beberapa penambahan, di antaranya seperti ca yang ditulis dengan 
huruf jim dengan titik tiga (ङ), nga ditulis dengan huruf 'ain dengan titik tiga di atasnya (๕)), $g a$ (untuk membedakan dengan gha) ditulis dengan huruf kaf dengan titik satu di atas atau di bawah (j), nya ditulis dengan huruf ya' dengan titik tiga di atas (ي)(Coolsma, 1985, hal. 10).

Tetapi, berbeda dengan huruf pegon yang memiliki sedikit perbedaan dengan huruf Arab biasa, aksara latin yang digunakan dalam penulisan tafsir Alquran tidak memiliki perbedaan dengan penggunaan aksara latin biasa. Ia berjumlah 26 huruf. Perbedaan akan muncul ketika ejaan lama (ejaan van Ophuijsen) masih digunakan, yaitu beberapa penulisan huruf seperti dj, j, oe, sj, tj, ch dan tanda angka dua di atas $\left({ }^{2}\right)$ untuk kata ulang yang berlaku sejak 1901. Ejaan ini kemudian digantikan oleh ejaan republik atau ejaan Soewandi sejak 1947 sehingga penulisannya menjadi j, y, u, sy, c, $\mathrm{kh}(J a m e s, 2003$, hal. 91). Begitu pula penulisan aksara latin digunakan untuk menuliskan bahasa Sunda dilakukan beberapa tambahan, seperti adanya huruf vokal é dan $e u$. Terjadi pula penyesuaian penulisan sesuai bunyi suara dalam pengucapan terhadap huruf konsonan tertentu yang jarang digunakan dalam urutan abjad bahasa Sunda, seperti "f, q, v, x, z, kh, sy"(Tamsyah, 2001, hal. 19). Beberapa huruf konsonan tersebut biasanya diubah penulisannya menjadi huruf "p, k, p, ks, j, h, s."

\section{Sekilas tentang K.H. Ahmad Sanoesi dan Karya-karyanya}

Sanoesi lahir di Sukabumi pada 18 September 1888. Ia dikenal sebagai ajengan, ulama pejuang dan perintis kemerdekaan dengan ratusan karya keagamaan yang kebanyakan berbahasa Sunda. Latar belakang keilmuan pesantren didapat dari ayahnya, Haji Abdurrahim, dan sejumlah pesantren di Priangan. Sebagai santri kelana, ia terhubung dengan jaringan pesantren Priangan. Sanoesi berguru pada para kiai sesuai dengan keilmuan yang hendak diperdalamnya. Ia pernah belajar setidaknya pada sembilan pesantren di Sukabumi, Cianjur, Garut dan Tasikmalaya. Selanjutnya, keterikatan Sanoesi dengan jaringan pesantren Sunda tersebut membuat dirinya juga terhubung dengan jaringan keilmuan Islam Nusantara, terutama setelah kepergiannya ke Mekah selama sekitar lima tahun (1909-1914). Di sini ia kemudian menjadi anggota Sarekat Islam (SI). Sepulangnya dari Mekah, ia kemudian dituduh pihak kolonial terlibat kasus SI-Afdeeling B, meski Sanoesi sendiri sudah lama mengundurkan diri dari SI. Tidak itu saja, pihak penjajah kemudian merasa semakin terganggu saat Sanoesi membuat kegaduhan terkait gugatannya atas kebijakan keagamaan hingga membuatnya dipenjara selama beberapa tahun lalu diasingkan ke Batavia Centrum tahun 1928. Di pengasingan inilah Sanoesi kemudian banyak menerbitkan karya-karyanya yang tersebar ke seluruh wilayah Priangan(Iskandar, 2001, hal. 308-310).

Sepulangnya dari pengasingan tahun 1932, Sanoesi lalu membangun pesantren Cantayan, Genteng, Syamsul Ulum dan terus menerbitkan sejumlah karya. Sanoesi lalu mendirikan organisasi Al-Ittihadijatoel Islamijjah (AII) lalu berubah menjadi PUI. Ia kemudian terlibat di PPKI dan BPUPKI tahun 1945 dan meninggal lima tahun kemudian di Sukabumi(Falah, 2009, hal. 176). Dari ratusan karya yang pernah dipublikasikannya, terdapat belasan karya tafsir Alquran yang ditulis dengan dua jenis aksara berbeda, yaitu huruf pegon dan aksara latin, di antaranya Pengadjaran dengan Bahasa Soenda atau Malja' al-Tālibīn fi Tafsir Kalam Rabb al-'Alamin, Tamsjijjatoel Moeslimien, Kashf al-Auham wa al-Zunun fi Bayan Qaulih Ta'ala la yamassuh illa al-Mutahharun, Raudatul 'Irfan fi Ma'rifatil Qur'an, Hidayat al-Qulub fi Fadl Surat Tabarak al-Mulk min al-Qur'an, Tafrih Qulub al-Mu'minin fi Tafsir Kalimat Surat Yasin, Kanz al-Rahmat wa al-Lutf fi Tafsir Surat al-Kahf, Tanbih al-Hairan fi Tafsir Surat al-Dukhan, Kashf al-Sa'adah fi Tafsir Surat Waqi'ah dan Silah al-'Irfan dan lain-lain(A.Rohmana, 2014, hal. 7).

Di antara sejumlah karya tafsirnya tersebut, tiga karya akan dikaji dalam kajian ini, yakni Raudat al-'Irfān dan Malja' al-Ṭälibìn yang menggunakan huruf pegon berbahasa Sunda dan Tamsjijjatoel Moeslimien yang menggunakan bahasa Indonesia beraksara latin. Tafsir Raudat al-'Irfān ditulis dengan menggunakan huruf pégon dengan sistem penulisan antar baris secara miring dan menggantung atau disebut dengan logat gantung. Tafsirnya secara singkat di letakkan di bagian pinggir. Terdiri dari dua jilid (Juz 1 s/d 15 dan Juz 16 s/d 30) (Sanoesi, n.d.-c). Tafsir ini diketahui disambut baik oleh para ulama pesantrén dan masyarakat luas di daerah Priangan tanpa ada protes dan penentangan sedikit 
pun. Tafsir ini bahkan telah mengalami puluhan kali cetak ulang hingga mencapai lebih dari 50.000 eksemplar.(Manshur, 1992, hal. 120) Sampai sekitar 1990-an, Raudat al-'Irfän masih menjadi salah satu kitab yang dipelajari di berbagai pesantren di Priangan(Bruinessen, 1990, hal. 237-238).

Sedangkan tafsir Malja' al-Tālibīn ditulis dengan huruf pegon berbahasa Sunda. Ia disusun sampai juz sembilan dalam 28 jilid. Tafsir ini diterbitkan saat Sanoesi berada dalam pembuangan di Batavia Centrum. Edisi pertama dicetak pada 28 Januari 1931. Pemasarannya umumnya di sekitar Priangan, Batavia, Banten hingga Purwakarta. Dari 28 jilid yang sempat terbit, 20 jilid diterbitkan di Batavia, sementara sisanya di Sukabumi. Setiap jilid rata-rata membahas tidak lebih dari setengah juz Alquran dengan kisaran ketebalan rata-rata 50 halaman. Di setiap sampul jilidnya tercantum pengumuman karangan Sanoesi lainnya, kadang berisi kritik pada kaum modernis, permintaan doa bagi konsumen yang wafat dan beberapa perbaikan(Sanoesi, n.d.-e).

Adapun tafsir Tamsjijjatoel Moeslimien, sebagaimana tafsir Malja' al-Tälibīn, diterbitkan dalam bentuk buletin atau majalah bulanan. Tafsir ini diterbitkan perdana pada 1 Oktober 1934 yaitu dua bulan setelah statusnya sebagai tahanan dipindahkan dari Batavia ke Sukabumi. Tafsir ini diterbitkan hingga edisi ke-53 atau hingga juz ke-8 Alquran. Tafsir ini didistribusikan secara luas hingga Batavia, Bandung, Belitung bahkan Singapura. Pada jilidnya dicantumkan pula harga tafsir itu yakni F. 0.40(Umar, n.d., hal. 156).

\section{Huruf Pegon dalam Raudat al-'Irfān dan Malja' al-Ṭālibīn}

Sebagaimana sudah dijelaskan huruf pegon memiliki beberapa perbedaan dengan huruf Arab biasa. Terdapat huruf Arab yang tidak digunakan seperti $t z, k h, d z, z, s y, d l$, tl, th, ' ('ain), g (ghain), $f$ dan $q$. Ada pula tambahan harakat untuk bunyi huruf é, eu dan o, serta terdapat tambahan huruf

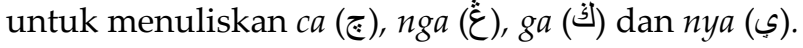

Tafsir berbahasa Sunda Malja' al-Tālibīn dan Raudat al-'Irfān karya Ahmad Sanoesi yang ditulis dalam huruf pegon juga menggunakan aturan huruf yang sama sebagaimana umumnya huruf pegon. Berikut akan ditunjukkan contoh penulisan huruf pegon dalam Raudat al-'Irfān ketika menafsirkan Q.S. Yünus[10]: 99 beserta transliterasinya dalam aksara latin yang dibuat oleh penulis(Sanoesi, n.d.-c, hal. 401).

Pada tafsir Malja' al-Ṭālibīn, seperti ketika menafsirkan QS. Al-Baqarah[2]:

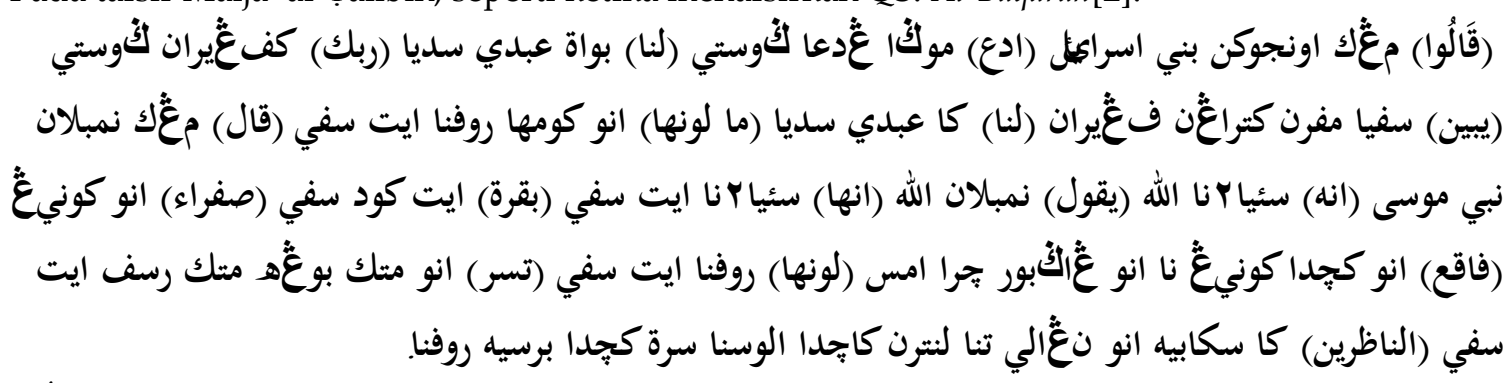

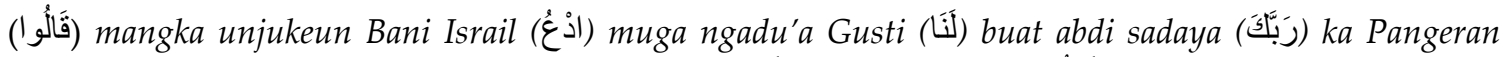

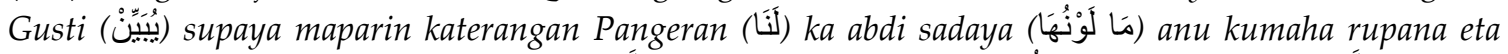

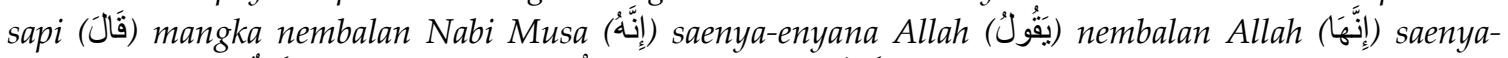

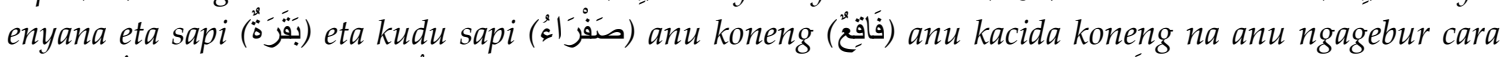

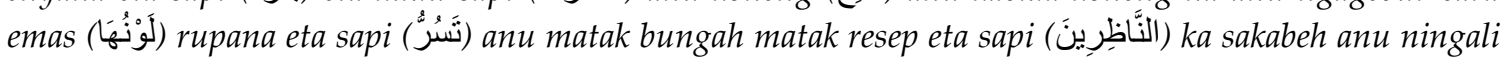
tina lantaran kacida alusna sarta kacida beresih rupana(Sanoesi, n.d.-f, hal. 59).

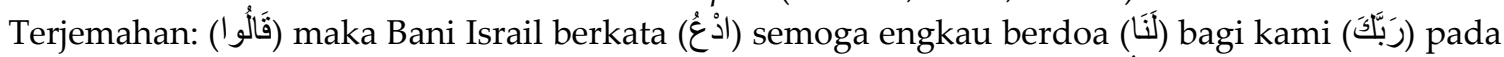

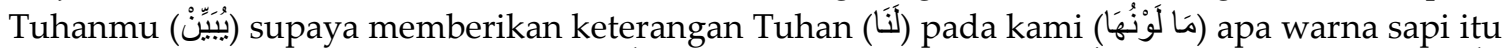

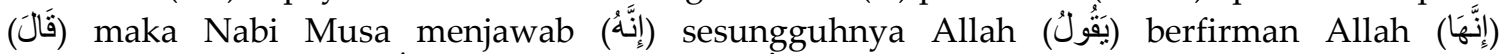

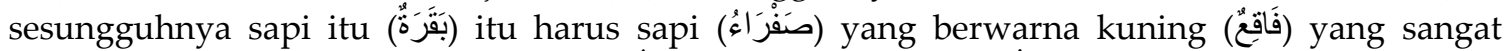

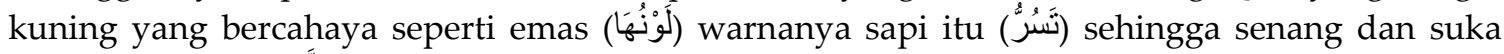
pada sapi itu (النَّاظِرِينَ) semua yang melihat karena sangat bagus dan bersih warnanya. 


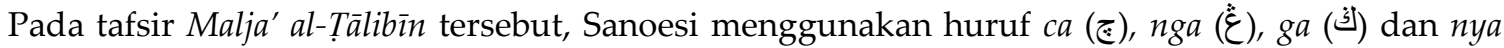
(؟). Huruf $c a$ (ङ) misalnya, tampak pada kata kacida dan cara; huruf nga (乡) misalnya, tampak pada kata mangka, ngadu'a, Pangeran, katerangan, koneng, ngagebur, bungah, ningali; huruf ga (ل) tampak pada kata gusti dan ngagebur; sedangkan huruf nya (ب) tampak pada kata saenya-enyana.

Sedangkan dalam kutipan tafsir Raudat al-'Irfān tersebut tampak menggunakan huruf nga ( $(\tilde{)})$ dan ga (ن). Huruf nga ( $(\hat{\varepsilon})$ misalnya, tampak pada kata jeung, ngersakeun, mangka dan tangtu. Sedangkan huruf ga (⿶) tampak pada kata tegesna. Seperti penafsiran berikut ini :

tabel 1 contoh penafsiran Surat Yünus ayat 99

\begin{tabular}{|c|c|c|c|c|c|}
\hline \multicolumn{2}{|c|}{ جميعا } & \multicolumn{2}{|c|}{ كلهم } & \multicolumn{2}{|c|}{ من في الأرض } \\
\hline 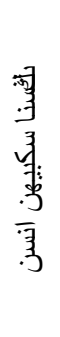 & 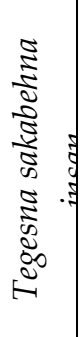 & 当: & 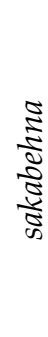 & 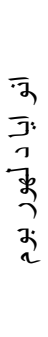 & 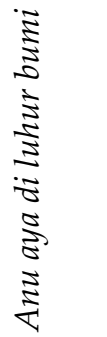 \\
\hline
\end{tabular}

\begin{tabular}{|c|c|c|c|c|c|c|}
\hline \multicolumn{2}{|c|}{ لأمن } & \multicolumn{2}{|c|}{ شاء ربك } & \multicolumn{3}{|c|}{ ولو } \\
\hline 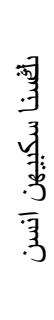 & 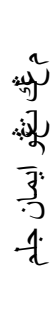 & 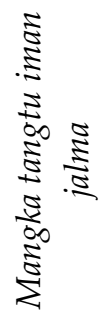 & 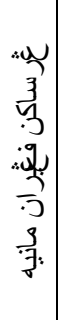 & 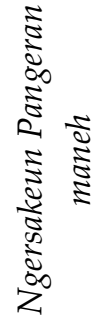 & כנّ & 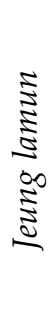 \\
\hline
\end{tabular}

\section{Aksara Latin dalam Tamsjijjatoel Moeslimien}

Adapun aksara latin digunakan oleh Sanoesi dalam tafsir Tamsjijjatoel Moeslimien juga sama dengan jumlah aksara latin pada umumnya, yaitu berjumlah 26 huruf dari a sampai z. Aksara latin yang digunakan dalam penulisan tafsir berbahasa Indonesia ini tidak memiliki perbedaan dengan penggunaan aksara latin biasa. Hanya saja tafsir ini masih menggunakan ejaan lama atau ejaan van Ophuijsen yang berlaku sejak 1901. Hal ini tampak pada beberapa penulisan huruf seperti dj, j, oe, sj, tj, ch, dan tanda angka dua di atas (2) untuk kata ulang yang masih digunakan dalam tafsirnya.

Berikut salah satu contoh penulisan aksara latin yang digunakan Sanoesi dalam Tamsjijjatoel Moeslimien ketika ia menafsirkan QS. Al-Baqarah[2]: 2.

Tabel 2 contoh penafsiran tafsir tamsjijatoel Moeslimien

\begin{tabular}{l|l}
\hline فيب الابه & Tiada ada sjak dan ragoe ${ }^{2}$ \\
\hline فيه & Didalem Qoerän itoe \\
\hline
\end{tabular}

Bahwa segala keadaan didalamnja itoe benar, dan dari pada Allah ta'ala, dan oleh karena Qoerän ini didjadikan patokan dan oendang ${ }^{2}$, boeat sekalian manoesia hidoepnja didoenia, soepaja teroes meneroes mendapat keselamatan, dan keoentoengan, dan kebahagiaan sampai kepada achirat, maka didjadikan permoelaannja keterangan segala bahagian manoesia,... (Sanoesi, n.d.-d, hal. 2829)

Dalam kutipan Tamsjijjatoel Moeslimien di atas, Sanoesi menggunakan bahasa Indonesia dengan aksara latin, tetapi ia masih menggunakan aksara latin dengan ejaan lama ejaan van Ophuijsen, seperti tampak pada beberapa penulisan kata seperti sjak, ragoe ${ }^{2}$, Qoerān itoe, didalamnja, itoe, didjadikan, oendang², boeat, manoesia, hidoepnja, didoenia, soepaja, teroes meneroes, keoentoengan, achirat, didjadikan, permoelaannja dan manoesia. Kata tersebut menggunakan ejaan seperti dj, j, oe, sj, tj, ch dan tanda angka dua di atas $\left({ }^{2}\right)$ untuk kata ulang. Hal ini dapat dipahami, karena Sanoesi menerbitkan karyanya Tamsjijjatoel Moeslimien sekitar tahun 1934. Sehingga ejaan van Ophuijsen masih berlaku saat itu.

\section{Huruf Pegon, Aksara Latin dan Segmentasi Pembaca}


Pemilihan aksara dalam sebuah literatur tafsir pada hakikatnya melibatkan pembaca. Mufasir akan menyesuaikan karyanya dengan tingkat pemahaman pembaca yang akan ditujunya. Karena bagaimanapun pembaca berkedudukan sebagai konsumen yang akan membeli produk karya tafsir yang diinginkannya. Di sinilah letak segmentasi pembaca yang senantiasa disadari oleh mufasir saat menulis karya.

Mufasir seperti Sanoesi karenanya menyadari bahwa terdapat pembaca yang berasal dari lingkungan pesantren yang bisa dipastikan mampu menguasai bahasa Arab, aksara Arab dan bahasa Sunda. Maka ia menulis tafsir Alquran yang ditulis dengan huruf pegon, karena kalangan santri dan kiai di pesantren terbiasa menggunakan huruf tersebut. Huruf pegon menjadi pilihan utama Sanoesi sejak awal karirnya sebagai pengarang buku-buku keislaman di tahun 1915. Sehingga karyanya dengan huruf pegon umumnya menyebar di berbagai pesantren di Priangan hingga sekarang.

Secara historis, penulisan tafsir dengan huruf pegon berbahasa Sunda terkait dengan latar pendidikan dan karirnya yang tidak jauh dari pesantren. Sebagaimana sudah dijelaskan, Sanoesi belajar di banyak pesantren sejak kecil. Selain belajar dari ayahnya, Haji Abdurrahim, ia juga belajar menjadi santri kelana di sejumlah pesantren di Priangan. Salah satu sumber menyebutkan bahwa setidaknya-tidaknya ada sembilan pesantren yang pernah dimasuki Sanoesi, baik yang ada di Sukabumi maupun yang ada di luar Sukabumi. Kesembilan pesantren itu adalah Pesantren Selajambe (Cisaat), Pesantren Sukamantri (Cisaat), Pesantren Sukaraja (Sukaraja), Pesantren Cilaku (Cianjur), Pesantren Ciajag (Cianjur), Pesantren Gudang (Tasikmalaya), Pesantren Gentur (Warungkondang, Cianjur), dan Pesantren Keresek serta Pesantren Bunikasih yang kedua-duanya berada di Garut

Karenanya, huruf pegon berbahasa Sunda sudah menjadi sarana Sanoesi dalam mempelajari berbagai kitab-kitab pesantren. Hal ini kemudian berlanjut ketika Sanoesi mengajar di pesantren milik ayahnya sekembalinya dari Mekah tahun 1915. Ia mengajar dengan menggunakan gaya bahasa Sunda yang mudah dimengerti oleh para santrinya, sehingga mendapat panggilan ajengan Cantayan. Begitu pun setelah Sanoesi menjalani hukuman tahanan kota di Batavia Centrum, ia kembali aktif di pesantren Cantayan dan melakukan rutinitasnya sebagai seorangan ajengan. Ia lalu mendirikan pesantren baru bernama pesantren Genteng tahun 1919 hingga ia juga dijuluki dengan ajengan Genteng.

Di pesantren inilah ia kemudian menerbitkan beberapa karya tafsir berhuruf pegon seperti Rauḍat al-'Irfān. Tafsir ini ditulis sebagai bagian dari kegiatan kepesantrenan. Ia merupakan hasil transmisi lisan saat pengajian yang disampaikannya tidak lama setelah Sanoesi kembali dari pengasingannya di Batavia. Tafsir ini ditulis ke dalam teks tulisan oleh sekitar 30 santrinya. Hasilnya kemudian dikumpulkan dan disalin ulang oleh penulis (kätib) yang dipercaya Sanoesi, yakni Muhammad Busyra dan kemudian dilanjutkan oleh Muhammad bin Yahya. Setelah mendapat persetujuan Sanoesi, hasil salinan tulis tangan kätib itu kemudian diperbanyak dengan cetak batu (litografi) di Pesantren Gunung Puyuh Sukabumi(Manshur, 1992, hal. 117-118). Dengan demikian, penggunaan huruf pegon berbahasa Sunda seperti tampak pada tafsir Raudat al-'Irfān tidak bisa dilepaskan dari aktifitas Sanoesi yang berasal dari lingkungan pesantren dan kemudian mengajar di pesantren. Ia menyadari bahwa karya tafsir yang ditulisnya memang diperuntukkan bagi kalangan pesantren Sunda di Priangan, bukan untuk kalangan umum yang lebih luas.

Hal ini berbeda dengan tafsir Tamsjijjatoel Moeslimien yang ditulis dalam bahasa Indonesia dengan aksara latin. Karya ini ditulis setelah Sanoesi menjalani masa pengasingan di Batavia Centrum. Pergaulannya yang luas semasa di organisasi SI di Mekah lalu berlanjut di Sukabumi, hingga mendirikan organisasi Al Ittihadijatoel Islamijjah (AII) yang kemudian berubah menjadi PUI menjadikannya sosok yang banyak bergaul dengan berbagai kalangan yang luas. Sanoesi tidak lagi menggunakan bahasa Sunda dalam pergaulannya di organisasi tersebut, tetapi menggunakan bahasa Indonesia. Karenanya, ketika menulis tafsir Tamsjijjatoel Moeslimien dalam bahasa Indonesia, aksara latin tentu saja menjadi pilihan utama, karena diperuntukkan bukan hanya untuk pembaca orang 
Sunda tetapi untuk semua orang Indonesia, sehingga penyebaran tafsirnya mencapai Belitung dan Singapura.

Dengan demikian, pilihan Sanoesi untuk menggunakan dua aksara yang berbeda dalam penulisan tafsir, kiranya karena dihadapkan pada segmentasi pembaca yang berbeda. Kondisi sosialkultural Sanoesi berada pada dua sisi yang berbeda, yakni di satu sisi ia dikenal sebagai ulama pesantren Sunda yang hidup di tengah-tengah kaum santri, tetapi di sisi lain ia juga menjadi aktifis SI lalu mendirikan sekaligus menjadi pimpinan AII yang memiliki pergaulan yang luas. Ia tidak hanya bergaul dengan kalangan pesantren, tetapi juga berbaur dengan berbagai kalangan seperti kaum menak, abangan, berpendidikan, termasuk juga para aktifis SI, PNI, Pasundan dan lainnya.

Pergaulan Sanoesi dengan berbagai kalangan masyarakat dari latar belakang berbeda-beda inilah yang menumbuhkan kesadaran untuk memberikan pengajaran tentang keislaman melalui literatur tafsir Alquran yang ditujukan pada khalayak yang lebih luas. Maka pilihan yang paling realistis adalah menggunakan bahasa Indonesia beraksara latin melalui tafsir Tamsjijjatoel Moeslimien tahun 1934. Hal ini kiranya tidak lepas dari situasi pasca Sumpah Pemuda 1928 di tengah peningkatan semangat nasionalisme yang semakin tumbuh, salah satunya diikat oleh bahasa yang satu, bahasa Indonesia. Seain itu, penggunaan transliterasi huruf Arab ke dalam aksara latin pada Tamsjijjatoel Moeslimien membuat pembaca yang belum dapat membaca Alquran dengan huruf Arab mudah membacanya. Selain itu, penggunaan bahasa Indonesia dalam aksara latin mempermudah pembaca awam untuk mempelajari ajaran Islam melalui karya tafsir. Hal ini sangat berbeda dengan Raudat al-'Irfān dan Malja' At Thalibīn yang ditulis dalam bahasa Sunda huruf pegon, kiranya hanya ditujukan untuk segmen pembaca yang terbatas, yaitu para santri dan kiai yang pasti mampu membaca huruf Arab dan hanya di lingkungan Priangan saja. Dalam salah satu pengantar awalnya yang berjudul "Tanbiehat (segala peringatan)" pada Tamsjijjatoel Moeslimien, Sanoesi menyatakan:

(1) Dimoehoenkan oleh saja jang dho'ief, kepada sekalian Toean² jang moelja, jang membatja ini Tafsier, djika melihat soeatoe kesalahan dari pada perkataan Melajoenja, atau dari pada soesoenannja, soedi kiranja membetoelkan dengan jang showab, dan memberi ma'af, karena saja boekan orang Malajoe dan boekan seorang jang mengalami sekolahan (Sanoesi, n.d.-d).

Kutipan tersebut tampak bahwa Sanoesi menunjukkan karyanya sejak awal ditujukan pada orang Melayu yang mengenyam pendidikan. Karenanya ia merasa perlu meminta maaf jika bahasa Melayu atau Indonesianya banyak kesalahan, karena ia sendiri bukan orang Melayu dan tidak pernah belajar di sekolah Belanda, melainkan hanya di pesantren.

Selain itu, untuk membuktikan perbedaan segmentasi konsumen pembaca tersebut, salah satunya dapat dilihat dari perbedaan penyebaran distribusi ketiga tafsir tersebut. Sebagaimana tampak dari pengumuman berita kematian atau tagihan tunggakan daftar para pelanggan yang di bagian akhir tafsirnya, bisa diketahui bahwa tafsir Malja' At Thalibin misalnya, karena ditulis dengan huruf pegon berbahasa Sunda, maka didistribusikan di beberapa daerah yang terbatas di Priangan, di antaranya Batavia atau Betawi, Bandung, Purwakarta, Bogor, Tasikmalaya, Ciamis, Rangkasbitung Banten. Kemudian daerah Sukabumi, seperti Cisaat, Malang, Rembang, Rawa Bantul, Pasar Tanjung, Tipar, Jantawana, Pasanggrahan Garut, Kubang Buleud, Nyalindung, Cibolong, Cimenteng, Cibolang dan Cikukulu(Sanoesi, n.d.-b, hal. 192, n.d.-a, hal. 118).

Hal ini tentu saja sangat berbeda dengan Tamsjijjatoel Moeslimien yang ditulis dengan bahasa Indonesia beraksara latin, maka jangkauan pemasarannya lebih luas. Meski tidak diketahui secara pasti penyebaran Tamsjijjatoel Moeslimien, tetapi dilihat dari bahasa dan aksara yang digunakan karya ini ditujukan untuk menjangkau pembaca yang banyak dan luas. Penyebaran tafsir ini kemungkinan menjangkau berbagai wilayah di hampir seantero Nusantara, seperti Jawa, Sumatera, Aceh dan bahkan Singapura(Umar, n.d., hal. 156). Karenanya, dibandingkan Raudat al-'Irfān dan Malja' At Thalibin, tafsir Tamsjijjatoel Moeslimien lebih mudah diakses untuk kalangan luas.

Pilihan aksara yang berbeda tersebut rupanya tidak hanya terbatas pada persoalan aksara dan bahasa saja, tetapi selanjutnya berpengaruh pula pada format dan substansi penafsiran ayat Alquran 
yang disesuaikan dengan khalayak segmen pembaca yang ditujunya seperti akan dijelaskan di bagian selanjutnya.

\section{Aksara dan Substansi Penafsiran Alquran}

Sebagaimana sudah dijelaskan, Sanoesi menggunakan dua jenis aksara dalam menerbitkan tafsir Alquran, yaitu huruf pegon dan aksara latin. Dari belasan karya tafsirnya, umumnya diterbitkan dalam huruf pegon dengan bahasa Sunda. Hal ini bisa terlihat dalam Malja' al-Tālibìn dan Raudat al'Irfān yang dijadikan objek kajian ini. Sedangkan Tamsjijjatoel Moeslimien diterbitkan dalam bahasa Indonesia beraksara latin.

Perbedaan penggunaan aksara dalam terbitan tafsir karangan Sanoesi tersebut tentu saja berdampak pada format dan penyajian tafsir yang berbeda pula. Malja' al-Tâlibìn dan Raudat al-'Irfān yang berhuruf pegon dengan bahasa Sunda yang diperuntukkan bagi pembaca dari kalangan santri pesantren, format penyajian dan substansi tafsirnya sesuai dengan tradisi kitab kuning di pesantren. Hal ini berbeda dengan Tamsjijjatoel Moeslimien yang menggunakan aksara latin berbahasa Indonesia. Format dan substansi tafsir dalam Tamsjijjatoel Moeslimien sangat jauh berbeda dengan tafsir behuruf pegon, kiranya diperuntukkan bagi kalangan pembaca yang lebih luas.

Berikut akan disajikan contoh format dan substansi penafsiran Sanoesi antara yang berhuruf pegon dalam Malja' al-Țälibìn dan Rauḍat al-'Irfān dengan tafsir yang beraksara latin, Tamsjijjatoel Moeslimien.

Dalam Tamsjijjatoel Moeslimien, Sanoesi tampak menyadari luasnya jangkauan pembaca tafsir berbahasa Indonesia beraksara latin tersebut. Ia misalnya, ketika menafsirkan kalimat wayuqimun alshalat (dan mereka mendirikan salat) dalam QS. Al-Baqarah[2]: 3, menjelaskan secara panjang lebar tentang bab salat termasuk perkara rahasia salat berjamaah dengan menyebut-nyebut pentingnya persatuan umat Islam dan persamaan antara orang marhaen dan ningrat, orang asing dan pribumi. Sebuah penjelasan yang jelas ditujukan untuk para pembaca yang terlibat aktif dalam aktifitas gerakan nasional.

\section{Rahsiah ${ }^{2}$ Sembahjang berdjamaah}

1. Mempersatoekan sekalian kaoem Islam, sekira2 sekalian mereka itoe berbaris dengan satoe barisan, dibelakang satoe Imam, soepaja masing2 kaoem Islam mengetahwi akan kewadjiban bersatoe didalam segala2nja tentang doenjanja dan agamanja.

2. Soepaja menoendjoekan atas persamaan diantara sekalian manoesia sekira2 sekalianja berbaris didalam satoe barisan tiada dibeda2kan orang2 jang kaja dari pada orang2 jang miskin, dan orang2 jang ningrat, dari pada orang2 jang marhaen, dan orang2 asing dari pada orang2 priboemi. Oleh karena itoe, maka sangat digemerkan sembahjang berdjama'ah itoe(Sanoesi, n.d.-d, hal. 17-18).

Penjelasan ayat tersebut jelas sangat berbeda dengan tafsir Raudat al-'Irfān dan Malja' al-Tālibīn yang lebih menekankan pada penafsiran yang umumnya dikenal kalangan santri bahkan dengan disertai penjelasan bab qira'at, sebuah keahlian diri Sanoesi yang pernah belajar qira'at di pesantren Keresek Garut. Dalam Malja' al-Tälibìn misalnya, Sanoesi menafsirkan kalimat wayuqimun al-salat dengan penjelasan:

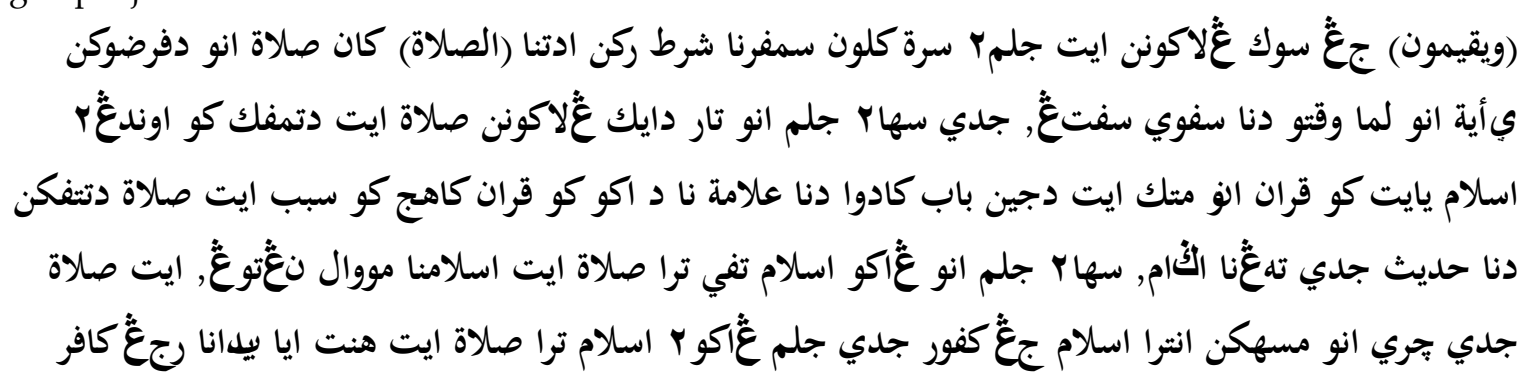

(Sanoesi, n.d.-b, hal. 17-18) 
(ويقيمون) jeung sok ngalakonan eta jalma2 sarta kalawan sampurna sarat rukun adatna (الصلاة) kana salat anu dipardukeun nyaeta anu lima waktu dina sapoe sapeuting, jadi saha2 jalma anu tara daek ngalakonan salat eta ditampik $k$ undang2 Islam nyaeta $k u$ Qur'an anu matak eta dijieun bab kadua dina alamatna diaku $k u$ Qur'an, kahiji ku sabab eta salat ditetepkeun dina hadis jadi tengahna agama, saha2 jalma anu ngaku Islam tapi tara salat eta Islamna moal nangtung, eta salat jadi cara anu misahkeun antara Islam jeung kupur jadi jalma ngaku2 Islam tara salat eta henteu aya bedana reujeung kapir.

Terjemahan: (ويقيمون) dan suka melaksanakan itu orang-orang serta dengan sempurna syarat dan rukun adatnya (الصلاة) pada salat yang difardukan, yaitu yang lima waktu dalam sehari semalam, jadi siapa orang yang tidak mau melakukan salat, maka ditolak oleh undang-undang Islam yaitu oleh Alquran, karenanya dibuat bab kedua dalam alamatnya yang diakui oleh Alquran, pertama dengan sebab salat itu ditetapkan dalam hadis menjadi setengahnya agama, siapa orang yang mengaku Islam tetapi tidak pernah salat maka Islamnya tidak tegak, salat itu menjadi cara yang memisahkan antara Islam dan kufur, jadi orang yang mengaku-ngaku Islam tetapi tidak pernah salat tidak ada bedanya dengan kafir.

Begitu pun ketika menafsirkan ayat tilka ummah qad khalat laha ma kasabat wa akum ma kasabtum wa la tus'alun 'amma kanu ya'malun (Itulah umat yang telah lalu. Baginya apa yang telah mereka usahakan dan bagimu apa yang telah kamu usahakan. Dan kamu tidak akan diminta (pertanggungjawaban) tentang apa yang dahulu mereka kerjakan) QS. Al-Baqarah[2]: 134, Sanoesi dalam Tamsjijjatoel Moeslimien menyebut nama Indonesia terkait pentingnya menjauhkan diri dari perpecahan. Sebuah penjelasan yang jelas tidak hanya terbatas ditujukan pada kalangan santri di pesantren, tetapi bagi pembaca umum yang lebih luas jangkauannya di seluruh Indonesia.

Dan siksaan bertjerai berai, itoe telah njata, dan terasa sakitnja, dan getirnja, oleh sekalian oemmat Islam Indonesia, dimasa sekarang, kerana djika diselidiki dengan sedjaoeh2nja, nistjajalah diboektikan tiada ada $20 \mathrm{pCt}$, jang masih teritoeng pantes makanannja, dan pakajannja, dan tempat tinggalnja, sedangkan tanah Indonesia itoe soeatoe tanah doenia jang paling soeboer dan jang paling kaja(Sanoesi, n.d.-d, hal. 413).

Hal ini berbeda dengan Malja' al-Tālibīn yang menjelaskan ayat dalam QS. Al-Baqarah[2]: 134 itu dengan menjelaskan maknanya perkata saja layaknya tafsir al-Jalalain yang biasa digunakan dalam kajian tafisr di pesantren, tanpa memberikan tafsiran yang terperinci sebagaimana Tamsjijjatoel Moeslimien.

$$
\begin{aligned}
& \text { (تلك) اري ايت نبي ابراهيم جغُ سكابيه فترا فتونا (امة) ايت امة (قد خلت) انو أثس كلوة تهلا ايت امة (لها) }
\end{aligned}
$$

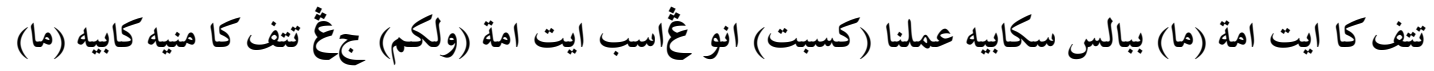

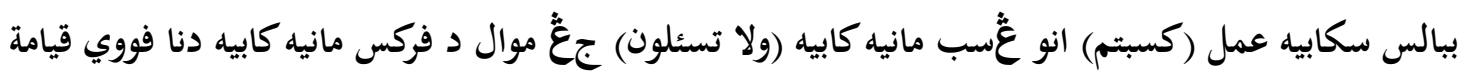

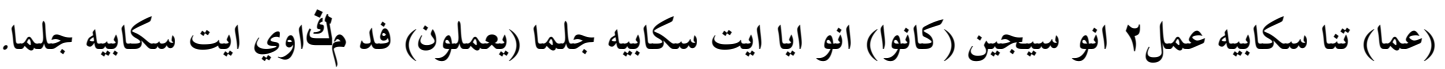

(Sanoesi, n.d.-f, hal. 111)

(تلك) ari eta Nabi Ibrahin jeung sakabeh putra putuna (ملث) خلت) eta uma geus kaliwat tiheula eta

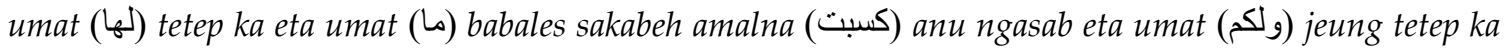
maneh kabeh (ما) babales sakabeh amal (كسبتر) anu ngasab maneh kabeh (و لا تسئلون) jeung moal dipariksa maneh kabeh dina poe kiamah (عما) tina sakabeh amal2 anu sejen (كانو) anu eta sakabeh jalma (كملون) pada migawe eta sakabeh jalma.

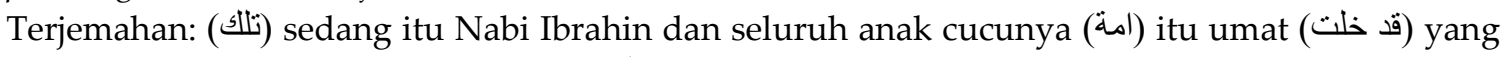

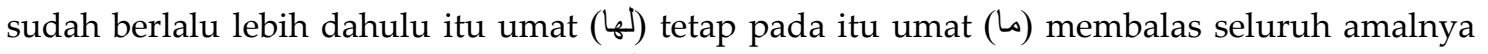

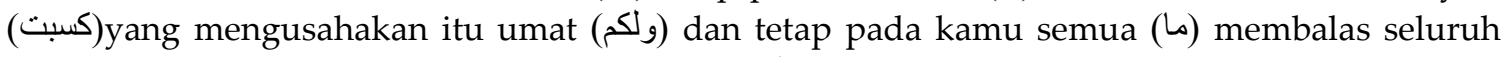
amal (كسبتم) yang mengusahakan kamu semua (ولام) لا تسئلون) dan tidak akan ditanya kamu pada hari

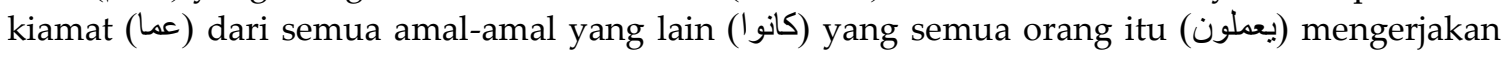
itu semua orang. 
Dengan demikian, penafsiran dalam Tamsiijjatoel Moeslimien terlihat lebih luas dan berkaitan dengan masalah kebangsaan, karena segmentasi dari pembaca tafsir ini adalah golongan masyarakat secara umum di luar kalangan pesantren, seperti kaum menak, abangan dan yang berpendidikan di sekolah Belanda. Hal ini berbeda dengan Raudat al-'Irfān dan Malja' At Thäibīn yang penafsirannya cenderung pada makna ayat secara terbatas ditambah dengan beberapa penjelasan qira'at. Hal ini sesuai dengan segmen pembaca yang ditujunya yang khusus bagi kalangan santri Sunda di Priangan. Dapat dikatakan bahwa kedua tafsir berhuruf pegon berbahasa Sunda tersebut penafsirannya terlihat lebih nyantri (sesuai selera santri) dibanding tafsir Tamsjijjatoel Moeslimien.

Karenanya, penjelasan di atas menunjukkan bahwa pilihan bahasa dan aksara yang digunakan mufasir seperti Sanoesi ditujukan untuk segmentasi pembaca tertentu yang pada gilirannya juga akan sangat berpengaruh terhadap substansi penafsirannya terhadap ayat Alquran. Inilah yang menjadi argumen penting mengapa pilihan huruf pegon dalam kasus tafsir karya Sanoesi sama sekali tidak terkait dengan upaya perlawanan simbolis terhadap kolonial, karena Sanoesi juga menggunakan aksara latin yang sejak awal dibawa oleh bangsa kolonial itu. Pilihan huruf pegon dan aksara latin kiranya lebih terkait dengan persoalan teknis penulisan yang disesuaikan dengan segmen pembaca yang dituju oleh Sanoesi antara pembaca kalangan santri Sunda di Priangan dan segmen pembaca non-santri yang lebih luas jangkauannya.

\section{Simpulan}

Literatur tafsir Alquran di Indonesia ditulis dengan bahasa dan aksara yang sangat beragam, pemilihan aksara ini erat kaitannya dengan kondisi sosial kultural di mana tafsir itu diproduksi. Kajian ini berhasil membuktikan bahwa penggunaan aksara tafsir salah satunya terkait dengan latar perbedaan segmentasi pembaca sehingga produk tafsir dapat dipasarkan secara tepat sasaran. Karya Ahmad Sanoesi Raudat al-'Irfān dan Malja' al-Tālibìn yang beraksara pegon dengan bahasa Sunda ditulis untuk kepentingan santri dan kiai pesantren di Priangan sebagai basis karir keilmuannya sehingga distribusi tafsirnya hanya di sekitar Priangan. Sedangkan Tamsjijjatoel Moeslimien yang beraksara latin berbahasa Indonesia ditulis untuk masyarakat lebih luas seiring dengan pergaulannya yang semakin luas terutama setelah aktif di organisasi SI, AII dan kemudian terlibat di PPKI, sehingga pemasaran tafsirnya menjangkau wilayah di luar Priangan, bahkan mencapai Sumatra dan Singapura. Pembedaan penggunaan dua jenis aksara tersebut juga berdampak pada substansi penafsiran Sanoesi terhadap ayat Alquran. Malja' At-Thäibīn dan Raudat al-'Irfān yang beraksara pegon lebih didominasi oleh penjelasan ayat melalui perangkat keilmuan Alquran yang umumnya hanya dapat dipahami oleh kaum santri secara terbatas, sedangkan Tamsijjjatoel Moeslimien yang beraksara latin didominasi penjelasan yang bercirikan kepentingan masyarakat umum agar dapat dipahami oleh khalayak luas. Karenanya, kiranya kurang tepat pandangan sebagian sarjana bahwa penggunaan huruf pegon oleh kalangan pesantren sebagai bentuk perlawanan terhadap kolonial yang mewacanakan aksara latin. Tetapi, sebagaimana dalam kasus Sanoesi, penggunaan huruf pegon sama sekali tidak ada hubungannya dengan bentuk perlawanan itu dibanding alasan keterbacaan karya oleh segmen pembaca yang berbeda-beda. Buktinya, meski Sanoesi dikenal sangat anti kolonial, tetapi Sanoesi menggunakan tidak hanya huruf pegon, tetapi juga aksara latin. Karenanya sangat tidak masuk akal bila penggunaan suatu aksara dihubungkan dengan upaya kalangan pesantren dalam meneguhkan simbol perlawanan kolonial

\section{Referensi}

A.H.Johns. (n.d.). "Penerjemahan" Bahasa Arab ke dalam Bahasa Melayu: Sebuah Renungan (H. Chambert-Loir, Ed.). Jakarta.

A.H.Johns. (1984). Islam in the Malay World: An Exploratory Survei with Some Reference to Quranic Exegesis. In Raphael Israeli and A.H. Johns, Islam in Asia. Jerussalem: Magnes Press.

A.H.Johns. (1988). Quranic Exegesis in the Malay-Indonesian World: In Search of Profile. In A. Rippin (Ed.), 
Approaches to the History of the Interpretation of the Qur' àn.

A.Rohmana, J. (2013). Ideologisasi Tafsir Lokal Berbahasa Sunda: Kepentingan Islam-Modernis dalam Tafsir Nurul-Bajan dan Ayat Suci Lenyepaneun. Journal of Qur'an and Hadith Studies, 2(1), 125-154.

A.Rohmana, J. (2014). Sejarah Tafsir Al-Qur'an di Tatar Sunda. Bandung: Mujahid Press-Diktis Kementerian Agama RI.

A.Rohmana, J. (2015). Al-Qur'ān wa al-Isti’mār: Radd al-Shaykh al-Ḥājj Ahmad Sanusi (1888-1950) ‘alá al-Isti’mār min Khilāl Tafsīr Mal'ja' al-Ṭālibīn. Studia Islamika, 22(2), 297-332.

A.Rohmana, J. (2017). Polemik Keagamaan dalam Tafsir Malja' al-Talibin Karya KH. Ahmad Sanusi. Suhuf, 10(1).

A.Teeuw. (1961). A Critical Survey of Studies on Malay and Bahasa Indonesia. B.V: Springer-Science+Business Media.

Asif, M. (2017). Tafsir Ahkam Pertama dari Pesatren: Telaah Awal atas Tafsīr Ayāt al-Aḥkām min al-Qur’ān alKarīm karya Abil Fadhal as-Senory. Suhuf, 10(2).

Baidan, N. (2003). Perkembangan Tafsir Al-Qur'an di Indonesia. Solo: Tiga Serangkai.

Basri, H. H. (2003). KH. Ahmad Sanusi: Membangun Format Ideal Relasi Agama dan Politik. In Transformasi Otoritas Keagamaan, Pengalaman Islam Indonesia (hal. 225-241). Jakarta: Gramedia.

Bilmauidhah. (2011). Puitisasi Terjemahan Quran: Studi Analisis Terjemahan Quran Bersajak Bahasa Aceh. IndoIslamika, 1(1), 41-62.

Bruinessen, M. van. (1990). Kitab kuning; Books in Arabic script used in the Pesantren milieu; Comments on a new collection in the KITLV Library'. In Bijdragen tot de Taal-, Land-en Volkenkunde (No. 2/3). Leiden.

Coolsma, S. (1985). Tata Bahasa Sunda (H. W. dan Y. Rusyana, Trans.). Jakarta: Penerbit Jambatan.

Darmawan, D. (2009). Ortodoksi Tafsir: Respon Ulama terhadap Tafsir Tamsjijatoel Moeslimin Karya K.H. Ahmad Sanoesi. Disertasi, Program Pascasarjana, UIN Syarif Hidayatullah Jakarta.

Falah, M. (2009). Riwayat Perjuangan K.H. Ahmad Sanusi. Masyarakat Sejarawan Indonesia Jawa Barat bekerjasama dengan Pemerintah Kota Sukabumi.

Federspiel, H. M. (1994). Popular Indonesian Literature of the Qur'an. Ithaca, New York: Cornel Modern Indonesia Project.

Fikri, I. (2014). Aksara Pegon, Studi tentang Simbol Perlawanan Islam di Jawa pada Abad XVIII-XIX.

Gusmian, I. (n.d.). Tafsir Al-Qur'an Bahasa Jawa, Peneguhan Identitas, Ideologi dan Politik. Suhuf, 9(1), 141-168.

Gusmian, I. (2010). Bahasa dan Aksara Tafsir Al-Qur'an di Indonesia, dari Tradisi, Hierarki hingga Kepentingan Pembaca. Thaqafah, 6(1).

Gusmian, I. (2013). Khazanah Tafsir Indonesia:Dari Hermeneutika hingga Ideologi (1st ed.). Yogyakarta: Lkis.

Gusmian, I. (2015). Bahasa dan Aksara dalam Penulisan Tafsir Al-Qur'an di Indonesia Era Awal Abad 20 M. Mutawatir, 5,(2), 233-247.

Gusmian, I. (2017). “K.H. Raden Muhammad Adnan (1889-1969 M): Ulama dan Pejuang di Bidang Pendidikan, Politik, dan Agama dari Kauman Surakarta. Jurnal Lektur Keagamaan, 15(1), 207-232.

Harun, S. (1988). Hakikat Tafsir Tarjuman Al-Mustafid Karya Syekh Abdurrauf Singkel. IAIN Syarif Hidayatullah Jakarta.

Haziyah Husin;Et.al. (2012). The Trend of Malay Quranic Commentary Writing in Malaysia in the 20th Century. Journal of Applied Sciences Research, 8(8).

Hussin, H., Majid, L. A., Mohd, N. S., Abdullah, W. N. W., \& Mohamad, S. (2016). Pemikiran Tafsir Sheikh Mohamed Idris al-Marbawi dalam Manuskrip Quran Bergantung Makna Melayu. Al-Turath Journal of AlQuran and Al-Sunnah, 1(1), 24-34. Retrieved from http:// spaj. ukm. my/jalturath/index. php/jalturath/ article/view/4

Iskandar, M. (2001). Para Pengemban Amanah, Pergulatan Pemikiran Kiai dan Ulama di Jawa Barat, 1900-1950. Yogyakarta: Mata Bangsa.

James, S. (2003). The Indonesian Language, Its history and role in modern society. Sydney: UNSW Press,.

Kiptiah, S. M. (n.d.). Tradisi Penulisan Tafsir Alquran Bahasa Jawa Cacarakan: Studi Atas Kur'an Jawen Muhammadiyah dan Tafsir Kur'an Jawen Pandam lan Pandoming Dumadi. Jurnal Lektur Keagamaan, 15(2), 420-445.

M.Feener, R. (2001). Southeast Asian Qur'anic Literature (General Editor), Encyclopaedia of the Qur'an (J. D. McAullife, Ed.). Leiden-Boston-Koln: Brill.

MacRaild, Donald M., dan Taylor, A. (2004). Social Theory and Social History. New York: Palgrave MacMillan.

Manshur, F. M. (1992). Ajaran Tasawuf dalam Raudhatul-'Irfan fi Ma'rifatil-Qur'an Karya Kyai Haji Ahmad Sanusi: Analisis Semiotik dan Resepsi. Universitas Gadjah Mada.

Matin, U. A. (2009). K.H. Ahmad Sanusi (1888-1950): His Religio-Intellectual Discourse, and His Work Collection. Lektur, 7(1), 147-164. 
Mohd Nazri Ahmad, M. F. M. S. (201AD). Metodologi Muhammad Sa'id Umar Terhadap Periwayatan HadithHadith Asbab al-Nuzul Dalam Tafsir Nurul Ihsan. Jurnal Al-Turath, 3(1).

Mursalim. (2009). Tafsir Bahasa Bugis/Tafsir Al-Qur'an Al-karim Karya Majelis Ulama Indonesia (MUI) Sulawesi Selatan. UIN Syarif Hidayatullah Jakarta.

Mustaqim, A. (2017). The Epistemology of Javanese Qur'anic Exegesis, A Study of Salih Darat's Fayd al-Rahman. Al-Jami'ah: Journal of Islamic Studies, 2, 55.

Riddell, HAL. G. (1989). Earliest Qur'anic Exegitical Activity in Malay-Speaking State". Archipel, 39.

Roger Tol,, Willem van der Molen, Uli Kozok, H. C. (2009). Aksara, Huruf, Lambang: Jenis-jenis Tulisan dalam Sejarah (H. Chambert-Loir, Trans.). Jakarta.

Rosmini. (2009). Revitalisasi Tafsir Lokal: Telaah atas fungsi ganda tafsir Mabbicara Ugi Tafsir al-Munir karya AGH. Daud Ismail al-Soppeniy. Jurnal Al-Qalam, 15(2), 199-214.

Saleh, M. (2016). K.H. Ahmad Sanusi, Pemikiran dan Perjuangannya dalam Pergolakan Nasional. Tangerang Selatan: Jelajah Nusa.

Sanoesi, A. (n.d.-a). Malja at Thalibin. Tanah Tinggi no. 191 Batavia Karamat.

Sanoesi, A. (n.d.-b). Pangadjaran Bahasa Soenda (Malja' al-Thalibin). Tanah Tinggi No. 191 Batavia Kramat: Kantor Cetak sareng Toko Kitab Al-Ittihad.

Sanoesi, A. (n.d.-c). Raudat al-'Irfän fi Ma'rifat al-Qur'ān (2nd ed.). Sukabumi: Pesantrén Gunung Puyuh.

Sanoesi, A. (n.d.-d). Tamsjijjatoel Moeslimin fie Tafsieri Kalami-Rabbil'alamien.

Sanoesi, A. (n.d.-e). Tapsir bahasa Soenda. No 8, Tanah Tinggi Senen No. 191 Batavia Kramat.

Sanoesi, A. (n.d.-f). Tapsir Basa Soenda (Malja' al-Talibin).

Seebohm, T. M. (2004). Hermeneutics, Method and Methodology. The Netherlands: Kluwer Academic Publishers.

Tamsyah, B. R. (2001). Galuring Basa Sunda,. Bandung: Pustaka Setia.

Umam, S. (2013). God's Mercy is Not Limited to Arabic Speakers: Reading Intellectual Biography of Muhammad Salih Darat and His Pegon Islamic Texts. Studia Islamika, 20(2).

Umar, H. H. (n.d.). Al-Turath al-'Ilmi li al-Islam bi Indunisiyya: Dirasah fi Tafsir Malja' al-Talibin wa Tamassiyah al-Muslimin li al-Shaikh al-Hajj Ahmad Sanusi. Studia Islamika, 8(1), 153-180.

Yusuf, M. (2013). Relevansi Pemikiran Ulama Bugis dan Nilai Budaya Bugis: Kajian tentang 'iddah dalam Tafsir berbahasa Bugis karya MUI Sulsel. Analisis, XIII(1), 57-78.

Zuhdi, M. N. (2012). Tipologi Tafsir al-Qur'an Mazhab Indonesia. Program Pascasarjana, UIN Sunan Kalijaga Yogyakarta.

Zulkifli bin Mohd Yusoff, H. B. M. (2005). Biografi Haji Mohd Said Dan Sejarah Penulisan Tafsir Nur Al-Ehsan. Al-Bayan: Journal of Al-Quran and Al-Hadith, 3, 65-82.

(C) 2020 by the authors. Submitted for possible open access publication under the terms and conditions of the Attribution 4.0 International (CC BY 4.0) license (https://creativecommons.org/licenses/by/4.0/). 